\title{
Policy Brief: An Interview with Education Advocates Juliane Baron and Michele McLaughlin
}

TRE Editor Devon Brenner recently sat down with experts to learn more about how to communicate with members of congress to advocate for rural education policy and funding. Juliane Baron is the Director of Government Relations at the American Educational Research Association. AERA, a national research society, strives to advance knowledge about education, to encourage scholarly inquiry related to education, and to promote the use of research to improve education and serve the public good. Michele McLaughlin is the President of Knowledge Alliance, an association that focuses on the federal role in education research, technical assistance and innovation.

TRE: Why is it important for people interested in rural education to speak up and engage with their members of congress?

Baron: There are some specific challenges that rural educators face that Members of Congress need to know about. If the rural educators who are most knowledgeable about and impacted by these challenges fail to bring them to the attention of Congressional offices, nobody else will and offices will not make rural education a priority when it is time to vote on the budget.

Congressional staffers are spread very thin working on a wide range of time sensitive issues. They receive a steady stream of correspondence and visitors demanding investment on everything from modernizing defense to building roads and bridges or accelerating the cure for cancer to supporting children in foster care. Everybody else is doing it and so if rural educators are not communicating regularly, Members of Congress may not be able to represent your needs. As one colleague says: "If you aren't at the table you are on the menu." Meaning the budget for the things that you care about will be cut or laws may be passed that hurt rural schools.

McLaughlin: In addition, staffers are interested in potential solutions to the challenges faced in rural communities, and they welcome the input of educators- who know their students and communities- on how to make improvements. After meeting with a group of rural educators, staffers are in the better position to brief Members of Congress, who are very interested in the perspective of their constituents. Educators may not know exactly what the federal government can do to help, but with their input, Members of Congress can find the right policy levers to make improvements.
TRE: We want to do a better job advocating for rural education. How should folks get started?

Baron: It is easier than you might think. It is always best to meet in person - but that doesn't have to be Washington, DC. Look to see where your Representative and Senators have their district offices. If possible, send an email requesting a brief meeting with the person who covers education indicating that you want to talk about challenges facing rural educators. If you are unable to make it to the office, phone calls and emails are also effective. Staff tracks every communication received by the office. When votes come up Members ask, 'What are we hearing from constituents? What do I need to know about rural education?' Your input matters to them. At AERA we have developed some resources, (http://cqrcengage.com/aeraedresearch/AERAAdvoca cyToolkit?0) including an Advocacy Handbook, (http://cqrcengage.com/aeraedresearch/file/NB9jOtE 4Iqh/Handbook2017_v6c3.pdf) for our members planning to visit with their Congressional offices for the first time.

Even better is to think about a way to build a relationship with the office. Consider inviting the Member or staff to visit your school or classroom. These can be terrific photo opportunities for the Member and valuable interactions to get them invested in issues specific to rural educators.

McLaughlin: I would also suggest looking for opportunities through the professional associations educators belong to; oftentimes these associations can facilitate making connections to Members of Congress. They also have staff who stay on top of legislation and can alert educators to when their voice needs to be heard. And, there is always power in numbers - the more a Member of Congress hears about the same issue from multiple constituents, the more likely they are to take action to make improvements. 
TRE: National associations really can be valuable resources. Weekly NREA UPdates from the executive director of our parent organization, the National Rural Education Association, provides current information about national policy that impacts rural education (http://www.nrea.net/NREA_UPdate), and the National Rural Education Advocacy Coalition (http://www.aasa.org/NREAC.aspx) can help readers connect to Members of Congress and understand rural education issues. Earlier you mentioned meeting with congressional staff. Shouldn't I expect to meet with my senator or representative herself?

Baron: In my experience meeting with staffers can be just as valuable as meeting with the Senator or Representative. Even when spread thin over numerous topics, staff cover a far smaller range of topics than their Members and tend to know more of the specifics of the issues. Despite staffers being surprisingly young, I have found them to be extremely knowledgeable and are more likely to engage in conversation where as Members are used to doing the majority of the talking, so you might have less of an opportunity to get your point across.

McLaughlin: When possible, Members of Congress will make every effort to also meet with constituents, even if they can only stop into the meeting for a few minutes. However, a lot depends on what is happening - whether a committee they sit on has a hearing or markup, or if there is a vote on the floor. Members of Congress also travel back to their home state during Congressional recess, so they are not usually in DC that week. Recognizing that they sometime miss the opportunity to see constituents, some Members of Congress hold a weekly breakfast where constituents can drop in and meet them. If you are planning a trip to DC, I would recommend calling the office ahead of time and asking if the Member has a "meet and greet" that you might attend.

TRE: How should rural education advocates prepare for a meeting or a phone call?

McLaughlin: It's best to assume you will only get a half hour with the staffer, as they are often in backto-back meetings when a piece of legislation is moving. When Congress is on recess, they often have more time, so meetings might run longer. Given the meeting will be relatively short, it's important to concisely describe your concerns and offer up possible solutions. I wouldn't bother leaving any materials in a fancy folder, as it will likely get thrown out. Some staffers prefer electronic documents only. If you are meeting with a staffer who is not on the education committee, you should provide a little more background on the issue before diving into the details. Non-committee staff, especially on the House side, often cover multiple issues, and given their background, might not have deep knowledge on education issues. Staff also want to know what the "ask" is--what is it you want them to do with the information you presenting. If you don't have an "ask," that's OK but try to let them know that early in the conversation.

Another tip: on the House side, conference room space is scarce, so don't be surprised if you end up meeting in the hallway standing up. It's not a reflection on you or the importance of the issue! Also, Congressional staff are addicted to their phones; don't be insulted if they check their emails multiple times during your half hour conversation. And, in my experience, staffers prefer follow-up by email. I'm not sure they actually talk on their phones.

Baron: I always recommend reading up on the background and priorities of the office that you are going to visit. Sometimes you can find an opportunity to make a nice topical or personal connection - which is a great way to start a meeting. As Michele wrote, it is critical to be concise. Practice what you plan to say, ask yourself if it is memorable and repeatable. These staffers could have up to seven or eight meetings on any given day - put a little thought into how to distinguish your meeting from all the othersthis is where the connection is so important.

When it comes to an "ask," I would also make it as easy as possible for them to help you. For example: you may ask them to vote for (or against) a particular bill, or make sure that funding for a particular program is included in the budget. Even when staffers are very supportive of your perspective, they are pulled in so many different directions and their to do lists are so long that if you can remove a step for them as they try to figure out how to show support issue, they are more likely to do so.

TRE: Is it better to bring multiple issues or focus on just one thing? Should I bring lots of research evidence to support my issue?

Baron: There is a temptation to take full advantage of your meeting and bring up a long list of important 
issues, but I would stick to one or at most two issues. Think of the meeting as a first date. If it goes well, you can mention an additional issue and share more research at a second meeting. Always offer to be a resource to the office if you are particularly knowledgeable about a topic. The goal is to build a relationship, so it is very valuable to have a reason to follow up.

McLaughlin: I would try to keep your message simple. The staffer will be most interested in your experience as a teacher or principal and what is working - or not - for students in your community. It helps to have research, but your expertise as an educator and the person closest to the students is most important, in my view.

TRE: Sometimes a Member of Congress has already issued a statement in favor or opposed to a piece of legislation or about funding. Should we still contact them anyway?

Baron: Definitely. If you have concerns about a piece of legislation, the office has no way of knowing if you do not take the time to tell them. I would try to start with the assumption that you have a shared goal of supporting education for students and framing your concerns as they may not be aware of the unintended consequences on rural schools.

McLaughlin: I agree that it's important for Members of Congress to hear directly from their constituents, even if they have already issued a position statement. It takes a long time for most education legislation to get reauthorized, and conditions on the ground can change. It took fourteen years to reauthorize ESEA, and a lot changed for schools during that time. Members of Congress have been known to change their positions on issues as more information, particularly from their communities, comes to the fore.

TRE: Do you have any final thoughts about communicating with legislators?

Baron: Make it happen! I have taken many of our AERA members on their very first Congressional visits. While it is common to wonder how much of an impact an individual meeting had, my members find the meetings educational, interesting and more often than not, fun! 